\title{
Time Series Behavior of Imports and Exports of Bangladesh: Evidence from Cointegration Analysis and Error Correction Model
}

\author{
Jashim Uddin \\ Senior Lecturer, Department of Business Administration, East West University, 43, Mohakhali C/A \\ Dhaka-1212, Bangladesh \\ Tel: 88-02-988-2308/274Ｅ-mail: juddin@ewubd.edu
}

\begin{abstract}
Bangladesh, a developing economy, contains trade deficit from her very inception. This paper makes an effort to understand the time series behavior of total export and total import of Bangladesh. Unit root tests recognize the existence of random walk in total export and total import time series. Johansen cointegration test reveals long-run equilibrium relationship between these two variables. Getting the existence of cointegration, the study attempts to find causal relationship using error-correction mechanism. Test results unveil bidirectional long term causality and unidirectional short term causality between import and export of Bangladesh. Findings of the study corroborate that Bangladesh is not in violation of its international budget constraints.
\end{abstract}

Keywords: Stationarity, Cointegration, Export, Import, Causality, Error-correction mechanism.

\section{Introduction}

International trade is the basic activity by which a country establishes its economic relationship with other countries. At present, liberalization of trade is a common phenomenon for most countries. Liberalization of trade policy significantly came into being in Bangladesh from 1991. Whatever is the concentration for liberalization, all the countries put extensive concern for gaining trade balance. A country's trade volume reflects the collective effects of other macroeconomic policies. To investigate collective effect of many policies on international trade, one can look for the long-run equilibrium relationship between export and import. Investigation regarding Bangladesh's export and import from time series perspective is not a new affair. But, as time moves on, researchers get continuously increasing room for analyzing time series behavior. So, I undertake investigation of time series behavior of Bangladeshi imports and exports considering all fiscal years (1972-73 to 2007-08) of independent Bangladesh.

Trade volume surely has effects of time as import and export demand of a country does not change overnight. Therefore, understanding time series behavior of trade volume can be insightful for trade policy analysis. In this connection, the study of time series behavior of trade volume has gathered weight in macroeconomic research.

In the literature there are several investigations relating to Bangladesh from the viewpoint of time series econometrics; such as Anam and Rahman (1991), Bhuiyan and Rashid (1993), Hossain (2000, 2001, 2003), Yilmaz and Verma (1995), Hossain $(2005,2006)$, Uddin et al (2008). The use of time series analysis, searching for random walk and cointegration, is extensive in macroeconomic literature. I outline some of those relating to trade and macroeconomic indicators, as Husted (1992), Powell (1991), Cuddington and Urza (1989), Deaton and Laroque (1989), Grilli and Yang (1988), Cochrane (1988).

Now, I am presenting the findings of some trade related studies available in the literature. Bahmani-Oskooee and Rhee (1997) found cointegration between exports and imports of South Korea. Bahmani-Oskooee (1998) used cointegration approach to find out the long run trade elasticities in least developed countries (LDCs). Tang (2006) studied cointegrating relationship between exports and imports of 27 selected Organization of the Islamic Conference (OIC) member countries. The study found cointegrating relationship between exports and imports of Bangladesh, Cameroon, Chad, Guyana, Indonesia, Mali, Morocco, Niger and Senegal; and all of them are developing countries. The remaining 18 countries provided no evidence of cointegration. Choong et al (2004) got cointegrating relationship between exports and imports of Malaysia. Cheong (2005) focused on several technical issues of Choong et al's work and concluded that cointegrating relationship between exports and imports of Malaysia cannot be generalized without considering several technical issues raised by him. Irandoust and Ericsson (2004) studied cointegrating relationship between exports and imports of some developed countries, named as France, Germany, Italy, Sweden, the UK and the USA. The study found cointegration for Germany, Sweden and the USA but it was rejected for the UK. Irandoust and Ericsson (2004) focused on policy implications of cointegrating relationship between exports and imports. According to Irandoust and Ericsson (2004), cointegrating relationship between exports and imports may explain that a country is not in violation of her international budget constraints and that trade imbalances are short term phenomenon and macroeconomic policies have 
been effective to bring exports and imports into equilibrium in the long-run. They (Irandoust and Ericsson) also concluded that no cointegration between exports and imports indicates major policy problems in the economy and the existence of productivity gap. So, cointegrating relationship between exports and imports cannot be attributed with either developed countries or developing countries. Arize (2002) explained that cointegration between exports and imports is an important element for formulating macroeconomic policies intended to achieve trade balance. Baharumshah et al (2003) got existence of cointegrating relationship between imports and exports for Indonesia, Philippines, Thailand, but not for Malaysia.

Tomšík (2001) investigated long term equilibrium relationship of Czech import and export function using 1993-1998 data. However, he found cointegrating relationship in the import function only. Wu and Zhang (1998) searched for cointegrating relationship between imports and exports of the USA with Japan, and found cointegrating relationship. Konya and Singh (2008) used 1949-50 to 2004-2005 trade data of India to find the existence of long-run equilibrium relationship and ended up with a result of no such relationship. Jalil (2008) investigated cointegrating relationship considering 1976-2006 data between exports and imports of Bangladesh and failed to get any such relationship, which is contradictory to the findings of Tang (2006). Narayan and Narayan (2004) found cointegrating relationship between exports and imports of both Fiji and Papua New Guinea.

\section{Background of Bangladeshi Trade Pattern}

Bangladesh, an emerging economy, experienced inward-looking economic philosophy in the 1970s. In the 1980s liberalization of trade and deregulation started and gradually moved forward. In the first half of 1990s level of liberalization became noteworthy as financial and capital accounts were liberalized. In the total time span of independent Bangladesh, it maintains sizeable trade deficit. As level of liberalization influences trade volume of a country, this study tries to portray some characteristics of Bangladeshi trade in pre liberalization (1972-1991) and post liberalization (1991-2008) period (Table 1). Table 1 explains that there are no significant differences in average growth rates of export and import in pre liberalization and post liberalization period. But there is significant difference in average growth rates of trade deficit between pre liberalization and post liberalization periods. Trade pattern of the total time span is also depicted in Figure 1.

\section{The Data}

The study considers yearly time series data of, i) nominal import value of Bangladesh (Imp), and ii) nominal export value of Bangladesh (Exp) ranging from 1972-73 to 2007-08 (all the fiscal years after the independence of Bangladesh). The study also include two ratio variables, which are nominal exports of Bangladesh as a percentage of her nominal GDP $(\operatorname{Exp} / G d p)$, and nominal imports of Bangladesh as a percentage of her nominal GDP $(\operatorname{Imp} / G d p)$. Data gathered from different publications of the Bangladesh Bank (BB) and the Ministry of Finance, Bangladesh. Ratio variables obtained through calculation and all the data series transformed to natural log form.

\section{Econometric Methodology}

Primarily this study tests the existence of unit root (random walk) in the aforesaid time series data. This study also requires investigation regarding cointegrating relationship between Imp and Exp, and between $\operatorname{Exp} / G d p$ and $\operatorname{Imp} / G d p$. This study employs unit root test for understanding the presence or absence of random walk (nonstationarity), which in turn, helps to determine the predictability of future values based on past values of a time series.

In the unit root tests, the augmented Dickey- Fuller (ADF) test consists of estimating the following regression:

$$
\Delta Y_{t}=\beta_{1}+\beta_{2} t+\delta Y_{t-1}+\alpha_{i} \sum_{i=1}^{m} \Delta Y_{t-i}+\epsilon_{t}
$$

where, $\Delta$ is the difference operator, $\epsilon_{t}$ is a white noise error term and

$\Delta Y_{t-1}=\left(Y_{t-1}-Y_{t-2}\right), \Delta Y_{t-2}=\left(Y_{t-2}-Y_{t-3}\right)$ etc. The null hypothesis is that $\delta=0$; that is there is a unit root and the alternative hypothesis is that $\delta<0$; that means the time series is stationary.

The Phillips and Perron (PP, 1988) test is based on estimating the following statistic.

$$
\xi_{\alpha}=t_{\alpha}\left(\frac{\gamma_{0}}{f_{0}}\right)^{\frac{1}{2}}-\frac{T\left(f_{0}-\gamma_{0}\right)(\operatorname{se}(\bar{\alpha}))}{2 f^{\frac{1}{2}}{ }_{0} S}
$$

Where, $\bar{\alpha}$ is the estimate, and $t_{\alpha}$ the $t$ ratio $\alpha, s e(\bar{\alpha})$ is the coefficient standard error, and $\mathrm{s}$ is the standard error of the test regression. In addition $\gamma_{0}$ is a consistent estimate of the error variance. The remaining term $f_{0}$, is an estimator of the residual spectrum at frequency zero. 
After the test of stationarity, this study uses Johansen $(1991,1995)$ cointegration test to identify the existence of any cointegrating relationship between Imp and Exp, and between $\operatorname{Exp} / G d p$ and $\operatorname{Imp} / G d p$. Whenever, someone gets two time series as nonstationary or $I(1)$ then $\mathrm{s} / \mathrm{he}$ can consider that the future values of a variable are not predictable based on past values. But there are still chances that two time series may share a common trend. That means, two variables are cointegrated if they have a long term equilibrium relationship between them.

The Johansen cointegration test $(1991,1995)$ is based on the following vector autoregression (VAR) equation.

$y_{t}=A_{1} y_{t-1}+\ldots .+A_{p} y_{t-p}+B x_{t}+\epsilon_{t}$

Where $y_{t}$ is a k- vector of non-stationary $I(1)$ variables, $x_{t}$ is a $d$-vector of deterministic variables and $\in_{t}$ is a vector of innovations.

The VAR can be rewritten as,

$\Delta y_{t}=\Pi y_{t-1}+\sum_{i=1}^{p-1} \Gamma_{i} \Delta y_{t-1}+B x_{t}+\epsilon_{t}$

where

$\Pi=\left(\sum_{i=1}^{p} A_{i}\right)-I \quad, \quad \Gamma_{i}=-\sum_{j=i+1}^{p} A_{j}$

If the coefficient matrix $\Pi$ has reduced rank $r<k$, then there exist $k \times r$ matrices $\alpha$ and $\beta$ each with rank $r$ such that $\Pi=$ $\alpha \beta^{\prime}$ and $\beta^{\prime} y_{t}$ is stationary. $r$ is the number of cointegrating relations and each column of $\beta$ is the cointegrating vector. Johansen proposes two different likelihood ratio test of significance named as trace test and maximum eigenvalue test, which are represented by following equations.

$Q_{\text {trace }}=-T \sum_{i=r+1}^{k} \log \left(1-\lambda_{i}\right)$

$Q_{\text {max }}=-T \log \left(1-\lambda_{r+1}\right)=Q_{r}-Q_{r+1}$

Here $T$ is the sample size and $\lambda_{\mathrm{i}}$ is the $i$-th largest eigenvalue. The trace statistic tests the null hypothesis of $r$ cointegrating vectors against the alternative hypothesis of $k$ cointegrating vectors. Whereas in the maximum eigenvalue statistic tests the null hypothesis of $r$ cointegrating vectors against the alternative of $r+1$ cointegrating vectors.

According to Granger (1988), if the variables are integrated of order $I(1)$ and are cointegrated, then there must exist at least oneway causation. If the variables are cointegrated, the existence of an error-correction representation may take the following form:

$$
\begin{aligned}
& \Delta X_{t}=\alpha+\sum_{i=1}^{m} \beta_{i} \Delta X_{t-i}+\sum_{j=1}^{n} \gamma_{j} \Delta Y_{t-j}+\delta E C M_{t-1}+u_{t} \\
& \Delta Y_{t}=a+\sum_{i=1}^{q} b_{i} \Delta Y_{t-i}+\sum_{j=1}^{r} c_{j} \Delta X_{t-j}+d E C M_{t-1}+v_{t}
\end{aligned}
$$

where $E C M$ explains the error-correction mechanism term. This $E C M_{t-1}$ is the one period lagged value of the estimated error of the cointegrating regression obtained from OLS (Ordinary Least Squares) estimation. The logic behind this model is that generally a long-run equilibrium relationship between two economic variables exists. But, in the short run there can be disequilibrium. Therefore, the error correction mechanism corrects a proportion of disequilibrium in the next period. So, the error correction process is an instrument of reconciling short-run and long-run behavior. In the error correction model, $\beta_{i} / b_{i} \& \gamma_{j} / c_{j}$ are the short-run dynamic coefficients and $\delta$ is the long-run coefficient, $u_{t} \& v_{t}$ are white-noise residuals. The absolute value of $\delta$ determines how quickly the equilibrium is restored. Conversely, in the absence of cointegration, a vector autoregression (VAR) needs to be constructed using first differences of the variables. In this case error correction term is excluded from the above specified equation. In identifying the causal relationship, the t-statistics explains the existence of long-run causality, while the significance of F-statistic indicates the presence of short-run causality.

\section{Empirical Results and Discussion}

I put all the four variables (Exp, Imp, Exp/Gdp, Imp/Gdp) for unit root tests to examine the nature of the variables as $I(0)$ or I(1). I summarize the results of each test in a single table for analytical ease. For the ADF test (Table 2.1) two time series (Imp and Imp/Gdp) show the existence of unit root in all the three different consequences using the level form of 
data. $\operatorname{Exp}$ and $\operatorname{Exp} / G d p$ series indicate stationarity or $I(0)$ at level form of data, only for the instance of constant \& linear trend. As first differences of a nonstationary time series are stationary (Gujarati 2003), I also conduct unit root test by using first differenced data of four variables. All the four variables show stationarity except one instance of $\operatorname{Exp}$ series (when considering 'none' option). Therefore, by considering results from level data and first differenced data I can consider all the data series as nonstationary or $I(1)$. The PP test (Table 2.2) signifies the existence of unit root in all cases at $1 \%$ level of significance, while considering first differenced data. But, by using the level data I get evidence of stationarity in $\operatorname{Exp}, \operatorname{Exp} / G d p$, and Imp/Gdp series, if considering constant \& linear trend. According to both the ADF and PP unit root tests, Exp and Exp/Gdp series have stationarity in level form of data, if constant and linear trend are considered. In contrast, both the series appear as stationary according to the ADF and PP unit root tests at $1 \%$ level of significance, considering first differences form of data. As such form of contradiction arises from a single instance (constant \& linear trend), it can be considered that all the four variables are nonstationary or $I(1)$. So there is possibility that $\operatorname{Exp} \& \operatorname{Imp}$, and $\operatorname{Exp} / G d p \& \operatorname{Imp} / G d p$ time series may move together in the long-run or may share a common trend in the long-run. As Exp \& Imp, and $\operatorname{Exp} / G d p \& \operatorname{Imp} / G d p$ time series are nonstationary; it is appropriate to carry out the cointegration test.

Table 3 posts results of pair wise Johansen's cointegration test under two different assumptions (no deterministic trend and linear deterministic trend). Johansen's conintegration test detects at least one cointegrating relationship between $\operatorname{Exp} \& \operatorname{Imp}$, and $E x p / G d p \& \operatorname{Imp} / G d p$ for both assumptions. Results of trace statistic and maximum eigenvalue statistics produce little contradiction, which is related to the significance level of cointegrating relationships. However, one should give more importance to trace statistics, as trace statistic considers all of the smallest eigenvalues, it holds more power than the maximum eigenvalue statistic (Kasa, 1992; Serletis and King, 1997). Moreover, Johansen and Juselius (1990) recommend the use of the trace statistic when these two statistics provide conflicting results. So, cointegrating relationship between Exp \& Imp, and $\operatorname{Exp} / G d p \& \operatorname{Imp} / G d p$ is evident; that means, Exp \& Imp and Exp/Gdp \& Imp/Gdp series share stable long-run relationships. Moreover, cointegrated import and export of a country explains that the country is not in violation of her international budget constraints and macroeconomic policies of the country have been effective in bringing total exports and imports into a long-run equilibrium (Irandoust and Ericsson 2004). So, the results of cointegration test of this study contradict with that of Jalil (2008). Such contradiction can be a result of differences in time periods or differences in calendar year data (used by Jalil, 2008) and fiscal year data (used in this study). It is important to note that, Tang (2006) found cointegrating relationship between exports and imports of Bangladesh.

As Granger (1988) spotlight on the possibility of causal relationship resulting from cointegration between or among the variables, I proceed to investigate unidirectional or bidirectional causality between Exp \& Imp, and Exp/Gdp \& $\operatorname{Imp} / G d p$. The cointegrated variables necessitate inclusion of the error-correction term as an added channel through which Granger causality can be revealed. According to Granger (1986), the ECM generates better short-run forecasts and provides the short-run dynamics necessary to obtain long-run equilibrium. From the technical point of view, the error-correction term measures the speed of adjustments to establish the long-run equilibrium.

Table 4 reveals long-run bidirectional causality between Exp \& Imp, as reflected by the coefficients of the error-correction terms and the respective t-values which are significant at $1 \%$. There is also evidence of short-run causality running from Imp to Exp, as the F-statistic is significant at $1 \%$ level of confidence. Exp/Gdp and Imp/Gdp are also having long-run bidirectional causality as expressed by the error-correction terms and the respective t-values' that are significant at 1\%. Exp/Gdp and $\operatorname{Imp} / G d p$ also hold bidirectional short-run causality that is portended by the significance of the F-statistics. Moreover, the significant error-correction term indicates that about $44 \%$ of disequilibrium is corrected each year by the changes in Imp to bring the long-run equilibrium between $\operatorname{Exp}$ and Imp. On the other hand, about $32 \%$ of disequilibrium is corrected each year by a decline in $\operatorname{Exp}$ to bring the long-run equilibrium between Exp and Imp. A similar type of explanation can be derived for $E x p / G d p$ and Imp/Gdp using the error-correction term indicated in Table 4.

\section{Conclusion}

This study reveals that total imports and total exports of Bangladesh follow random walk or are considered as nonstationary time series. There is also evidence of long-run cointegrating relationship between Exp \& Imp, and $E x p / G d p \& I m p / G d p$, as the Johansen cointegration test detect at least one cointegrating equation for both the pairs. As cointegrated variables are expected to have causal relationships, I investigate the causal relationship between Exp \& Imp, and $E x p / G d p \& I m p / G d p$ by specifying the error-correction mechanism. According to the results, long-run bidirectional causality exists between Exp \& Imp, and short-run unidirectional causality exists from Imp to Exp. Moreover, bidirectional short-run and long-run causality exist between $\operatorname{Exp} / G d p$ and $\operatorname{Imp} / G d p$. So, according to Irandoust and Erricsson (2004), Bangladesh is not in violation of its international budget constraints and trade imbalances of Bangladesh are a short-run event, which in the long-run are sustainable. Cointegrating relationship of trade also explains an economy as well-functioning because the deficits are evanescent that will be balanced by future surpluses. 
Therefore, the macroeconomic policies of Bangladesh have been effective in bringing total exports and imports into a long-run equilibrium.

\section{References}

Anam, M., \& Rahman, S. S. (1991). Economic in South Asia: an exploratory analysis in trade, investment and finance. Journal of Developing Societies, 7, 139-158.

Arize, A. C. (2002). Imports and exports in 50 countries: test of cointegration and structural breaks. International Review of Economics and Finance, 11(1), 101-15.

Baharumshah, A. Z., Lau, E., \& Fountas, S. (2003) On the sustainability of current account deficits: evidence from four ASEAN countries. Journal of Asian Economics, 14 (3), 465-87.

Bahmani-Oskooee, M. (1998). Cointegration approach to estimate the long-run trade elasticities in LDCs. International Economic Journal, 12 (3), 89-96.

Bahmani-Oskooee, M., \& Rhee , H. J.(1997). Are imports and exports of Korea cointegrated? International Economic Journal, 11 (1), 109-14.

Bhuiyan, A. R., \& Rashid, M. A. (1993). Trade regimes and industrial growth: a case study of Bangladesh. Bureau of Economic Research, D. U. and International Center for Economic Growth, San Francisco, U.S.A.

Cheong, T. T. (2005). Are Malaysian exports and imports cointegrated? a comment. Sunway Academic Journal, 2 , 101-107.

Choong, C. K., Soo, S. C., \& Zulkornain, Y. (2004). Are Malaysian exports and imports cointegrated?. Sunway College Journal, 1, 29-38.

Cochrane, J. H. (1988). How big is the random walk in GNP?. Journal of Political Economy, 96 (5), 111-117.

Cuddington, J. T., \& Urzua, C. M. (1989). Trends and cycles in the net barter terms of trade: a new approach. The Economic Journal, 99, 426-442.

Deaton, A., \& Laroque, G. (1989). On the behaviour of commodity prices. Mimeo, Princeton University.

Granger, C. W. J. (1986). Development in the study of cointegrated economic variables. Oxford Bulletin of Economics and Statistics, 48, 213-228.

Granger, C. W. J. (1988). Some recent developments in the concept of causality, Journal of Econometrics, 39 (1), 199-211.

Grilli, E. R., \& Yang, M. C. (1988). Primary commodity prices, and the terms of trade of developing countries: what the long run shows. The World Bank Economic Review, 2, 1-47.

Gujarati, D. N. (2003). Basic Econometrics. (4 ${ }^{\text {th }}$ ed.).New York: The McGraw-Hill companies Inc., (Chapter 21).

Hossain, M. K. (2000). International trade with SAARC and the trade policies of Bangladesh. Journal of Economic Cooperation, 21 (3), 99-152.

Hossain, M. K. (2001). Is SAARC a variable bloc? evidence from gravity model. Journal of Asian Economics, 12, 263-290.

Hossain, M. K. (2003). Regional cooperation in trade, finance and investment among SAARC countries: the Bangladesh perspective. Thought on Economics, 13, 7-30.

Hossain, M. S. (2005). Are the Bangladesh exports to and imports from India cointegrated?. Journal of Business Studies, $26(1), 125-141$.

Hossain, M. S. (2006). An empirical investigation on the time series behavior of trade deficit between Bangladesh and Sri Lanka. The Cost and Management, 34 (1), 66-79.

Husted, S. (1992). The emerging U.S. current account deficit in the 1980s: a cointegration analysis. The Review of Economics and Statistics, 74 (1), 159-166.

Irandoust, M., \& Ericsson, J. (2004). Are imports and exports cointegrated? an international comparison. Metroeconomica, 55 (1), 49-64.

Jalil, M. M. (2008) Are exports and imports of Bangladesh cointegrated?. Working Paper Series, North South University, Bangladesh.

Johansen, S. (1991). Estimation and hypothesis testing of cointegration vectors in gaussian vector autoregressive models. Econometrica, 59 (6), 1551-1580.

Johansen, S. (1995). Likelihood-based inference in cointegrated vector autoregressive models. Oxford University Press. 
Johansen, S., \& Juselius K. (1990). Maximum likelihood estimation and inferences on cointegration with applications to the demand for money. Oxford Bulletin of Economics and Statistics, 52 (2), 169-210.

Kasa, K. (1992). Common stochastic trends in international stock markets. Journal of Monetary Economics, 29 (1), 95-124.

Koyna, L., \& Sing, J. P. (2008). Are Indian exports and imports cointegrated?. Applied Econometrics and International Development, 8 (2), 177-186.

Narayan, P. K., \& Narayan, S. (2004) Is there a long-run relationship between exports and imports? Evidence from two Pacific island countries. Economic Papers, 23 (2), 152-164.

Phillips, P.C.B., \& Perron, P. (1988). Testing for a unit root in time series regression. Biometrika, 75 (2), $335-346$.

Powell, A. (1991). Commodity and developing country terms of trade: what does the long run show?. The Economic Journal, 101 (5), 1485-1496.

Serletis, A., \& King, M. (1997). Common stochastic trends and convergence of European stock markets. The Manchester School, 65 (1), 44-57.

Tang, T. C. (2006). Are imports and exports in the OIC member countries cointegrated? a reexamination. IIUM Journal of Economics and Management. 14 (1), 1-31.

Tomšík, V. (2001). Cointegration analysis of foreign trade in the Czech Republic, 1993-98. Czech Journal of Economics and Finance, 51 (7-8), 417-429.

Uddin, J., Khan, M. H., Rahman, L., \& Parvin, S. (2008). Time series behavior of Bangladesh-Japan trade: an econometric analysis. Journal of Business Studies, 29 (1), 169-186.

Wu, Y., \& Zhang, J. (1998). Are the U.S. exports to and imports from Japan cointegrated?. Journal of Economic Integration, 13 (4), $626-643$.

Yilmaz, K., \& Varma, S. (1995). Trade policy reform in Bangladesh. Bangladesh Industrial Surveys and Studies Program, Working Paper, World Bank, Dhaka.

Table 1. Average growth rate of trade components

\begin{tabular}{|l|r|r|r|}
\hline \multicolumn{1}{|c|}{ Trade components } & \multicolumn{1}{|c|}{$1972-1991$} & $1991-2008$ & $1972-2008$ \\
\hline \% of average export growth & 20.5631 & 18.1179 & 19.3754 \\
\hline \% of average import growth & 19.5672 & 16.0300 & 17.8492 \\
\hline \% of average growth in trade deficit & 23.0413 & 14.4967 & 18.8911 \\
\hline
\end{tabular}

Table 2.1. Unit Root Test Using ADF (Calculated and critical values)

\begin{tabular}{|l|c|c|c|c|c|c|}
\hline \multirow{2}{*}{ Variables } & \multicolumn{2}{|c|}{ Constant } & \multicolumn{2}{c|}{ Constant \& Linear } & \multicolumn{2}{c|}{ None } \\
\cline { 2 - 7 } & Levels & $1^{\text {st }} \Delta$ & Levels & $1^{\text {st }} \Delta$ & Levels & $1^{\text {st }} \Delta$ \\
\hline $\operatorname{Exp}$ & -1.0095 & $-8.1475^{* *}$ & $-3.6333^{*}$ & $-8.1015^{* *}$ & 5.3032 & -1.1627 \\
\hline $\operatorname{Imp}$ & -0.7716 & $-8.7377^{* *}$ & -3.0857 & $-8.8881^{* *}$ & 4.9660 & $-2.2116^{*}$ \\
\hline$E x p / G d p$, & -0.8422 & $-7.1617^{* *}$ & $-4.5544^{* *}$ & $-8.1863^{* *}$ & -1.8458 & $-6.7700^{* *}$ \\
\hline $\operatorname{Imp} / G d p$ & -2.1270 & $-9.1167^{* *}$ & -3.3483 & $-8.9330^{* *}$ & -0.7344 & $-8.9633^{* *}$ \\
\hline Critical value 1\% & -3.6394 & -3.6394 & -4.2436 & -4.2528 & -2.6347 & -2.6392 \\
\hline Critical value 5\% & -2.9511 & -2.9511 & -3.5442 & -3.5484 & -1.9510 & -1.9516 \\
\hline Notes: & & & \\
1. Using critical values by Mackinnon, 1996 & & \\
2. $*$ indicates stationarity at 5\% level and ** indicates stationarity at 1\% level \\
3. Lag length automatically chosen (by EViews 5) using Schwarz Information Criterion (SIC) \\
\hline
\end{tabular}

Table 2.2. Unit Root Test Using Phillip-Perron (Calculated and critical values)

\begin{tabular}{|l|c|c|c|c|c|c|}
\hline \multirow{2}{*}{ Variables } & \multicolumn{2}{|c|}{ Constant } & \multicolumn{2}{c|}{ Constant \& Linear } & \multicolumn{2}{c|}{ None } \\
\cline { 2 - 7 } & Levels & $1^{\text {st }} \Delta$ & Levels & $1^{\text {st }} \Delta$ & Levels & $-3.7889^{* *}$ \\
\hline $\operatorname{Exp}$ & -0.3244 & $-8.2468^{* *}$ & $-3.6004^{*}$ & $-8.1015^{* *}$ & 6.9484 & $-4.7867^{* *}$ \\
\hline $\operatorname{Imp}$ & -0.7716 & $-8.6838^{* *}$ & -2.9169 & $-8.8881^{* *}$ & 6.4346 & $-6.7700^{* *}$ \\
\hline $\operatorname{Exp} / G d p$, & 0.0331 & $-9.5396^{* *}$ & $-4.6328^{* *}$ & $-10.0714^{* *}$ & -1.7431 & $-9.4026^{* *}$ \\
\hline $\operatorname{Imp} / G d p$ & -1.9475 & $-9.7891^{* *}$ & $-3.5677^{*}$ & $-9.5708^{* *}$ & -0.8736 & -2.6347 \\
\hline Critical value 1\% & -3.6329 & -3.6394 & -4.2436 & -4.2528 & -2.6326 & 1.9510 \\
\hline Critical value 5\% & -2.9484 & -2.9511 & -3.5442 & -3.5484 & -1.9506 & \\
\hline Notes: 1. Using critical values by Mackinnon, 1996 & \\
2. * indicates stationarity at 5\% level and ** indicates stationarity at 1\% level \\
3. Bandwidth chosen according to Newey-West using Bartlett kernel \\
\hline
\end{tabular}


Table 3. Results of Johansen cointegration test (pair wise)

\begin{tabular}{|c|c|c|c|c|}
\hline Null hypothesis & $\begin{array}{c}\text { Alternate } \\
\text { hypothesis }\end{array}$ & Variables & Trace statistic & $\begin{array}{c}\text { Max-Eigenvalue } \\
\text { statistic }\end{array}$ \\
\hline $\mathrm{r}=0$ & $\mathrm{r}=1$ & \multirow{2}{*}{$\begin{array}{l}\text { Exp/Imp } \\
\text { No deterministic trend }\end{array}$} & $33.6215^{* * *}$ & $28.9167 * * *$ \\
\hline $\mathrm{r} \leq 1$ & $\mathrm{r}=2$ & & 4.7048 & 4.7048 \\
\hline $\mathrm{r}=0$ & $\mathrm{r}=1$ & \multirow{2}{*}{$\begin{array}{l}\text { Exp/Imp } \\
\text { Linear deterministic trend }\end{array}$} & $27.2017 * *$ & $17.4673 *$ \\
\hline $\mathrm{r} \leq 1$ & $\mathrm{r}=2$ & & 9.7343 & 9.7343 \\
\hline $\mathrm{r}=0$ & $\mathrm{r}=1$ & \multirow{2}{*}{$\begin{array}{l}(\operatorname{Exp} / G d p) /(\operatorname{Imp} / G d p) \\
\text { No deterministic trend }\end{array}$} & $22.4417 * *$ & $21.0594 * * *$ \\
\hline $\mathrm{r} \leq 1$ & $r=2$ & & 1.3822 & 1.3822 \\
\hline $\mathrm{r}=0$ & $\mathrm{r}=1$ & \multirow{2}{*}{$\begin{array}{l}(\operatorname{Exp} / G d p) /(\operatorname{Imp} / G d p) \\
\text { Linear deterministic trend }\end{array}$} & $27.6197 * *$ & $17.7634 *$ \\
\hline $\mathrm{r} \leq 1$ & $\mathrm{r}=2$ & & 9.8563 & 9.8563 \\
\hline Null hypothesis & $\begin{array}{c}\text { Alternate } \\
\text { hypothesis }\end{array}$ & Level of Critical values & Trace statistic & $\begin{array}{c}\text { Max-Eigenvalue } \\
\text { statistic }\end{array}$ \\
\hline $\mathrm{r}=0$ & $\mathrm{r}=1$ & \multirow{2}{*}{$\begin{array}{l}\text { at } 5 \% \\
\text { No deterministic trend }\end{array}$} & 20.2618 & 15.8921 \\
\hline $\mathrm{r} \leq 1$ & $\mathrm{r}=2$ & & 9.1645 & 9.1645 \\
\hline $\mathrm{r}=0$ & $r=1$ & \multirow{2}{*}{$\begin{array}{l}\text { at } 5 \% \\
\text { Linear deterministic trend }\end{array}$} & 25.8721 & 19.3870 \\
\hline $\mathrm{r} \leq 1$ & $\mathrm{r}=2$ & & 12.5179 & 12.5179 \\
\hline \multicolumn{5}{|c|}{$\begin{array}{l}\text { Note: } \\
\text { 1. Critical values based on MacKinnon-Haug-Michelis (1999) } \\
\text { 2. * indicates significance at } 10 \% \text { level, ** indicates significa } \\
\text { 3. Considered lag length } 2 \text { according to LR (likelihood ratio) te }\end{array}$} \\
\hline
\end{tabular}

Table 4. Results of Error-correction/Causality

\begin{tabular}{|c|c|c|c|c|}
\hline $\begin{array}{l}\text { Dependent } \\
\text { variable }\end{array}$ & Causal variable & F-statistics & Constant (t-statistic) & $\begin{array}{l}\text { Error correction term } \\
\text { (t-statistic) }\end{array}$ \\
\hline$\Delta \operatorname{Exp}$ & $\Delta \operatorname{Imp}$ & $5.8789^{* *}$ & $3.8322(10.0380)^{* *}$ & $0.4424(5.5616)^{* *}$ \\
\hline$\Delta \operatorname{Imp}$ & $\Delta \operatorname{Exp}$ & 2.5223 & $-3.0699(-12.5654)^{* *}$ & $-0.3201(-3.0832)^{* *}$ \\
\hline$\Delta \operatorname{Exp} / G d p$ & $\Delta \operatorname{Imp} / G d p$ & $3.3769 *$ & $0.0561(1.6189)$ & $0.4402(3.0884)^{* *}$ \\
\hline$\Delta \operatorname{Imp} / G d p$ & $\Delta \operatorname{Exp} / G d p$ & $4.9685 * *$ & $-0.0859(-3.4634)^{* *}$ & $-0.1601(-4.2989)^{* *}$ \\
\hline \multicolumn{5}{|c|}{$\begin{array}{l}\text { Note: } \\
\text { 1. } \Delta \text { indicates first difference } \\
\text { 2. lag length kept similar to the lag length used for cointegration test } \\
\text { 3. No deterministic trend included in the VAR equations } \\
\text { 4. } * \text { indicates significance at } 5 \% \text { level and } * * \text { indicates significance at } 1 \% \text { level }\end{array}$} \\
\hline
\end{tabular}

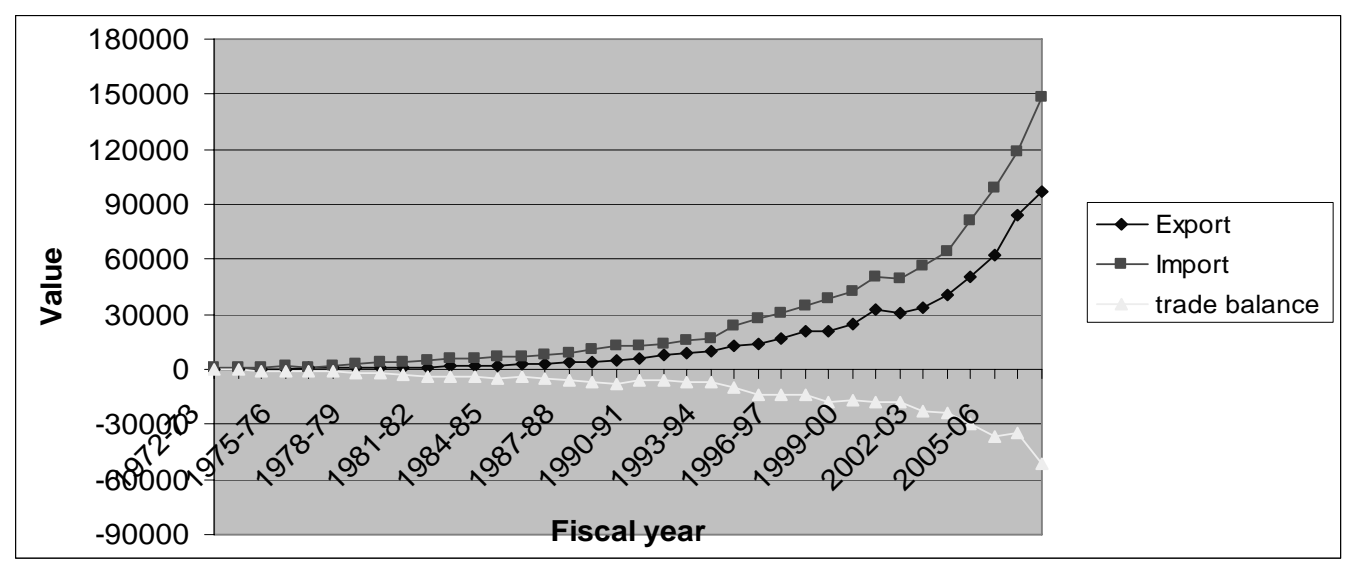

Figure 1 Value of exports, imports and trade balance 